\title{
Decolourisation of Reactive Black 5 by Azoreductase Produced by Brevibacillus panacihumi ZBI
}

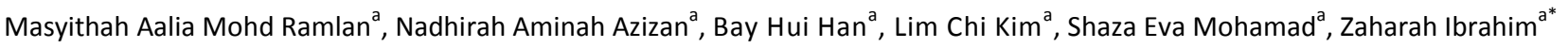 \\ ${ }^{a}$ Faculty of Bioscience and Bioengineering, Universiti Teknologi Malaysia, 81310, UTM Johor Bahru, Johor Darul Ta'azim, Malaysia \\ *Corresponding author: zaharah@fbb.utm.my
}

\section{Article history}

Received :1 August 2012

Received in revised form :7 Sept. 2012

Accepted :1 October 2012

\section{Graphical abstract}

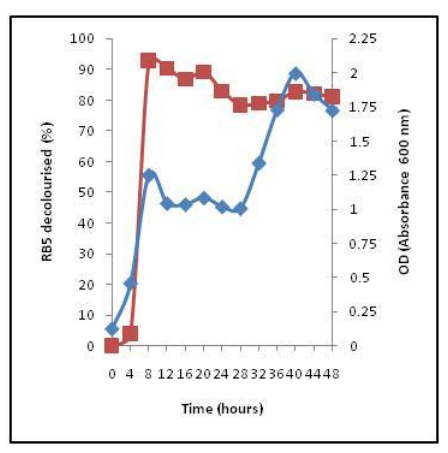

\begin{abstract}
Azoreductases are often associated with decolourisation of non-degradable azo dyes via cleavage of azo bonds. In this study, Brevibacillus panacihumi ZBI, an azo dye-degrading bacterium which has not been reported before, was used for the decolourisation of Reactive Black 5 (RB5) dye. The highest activity of azoreductase was obtained during the end of log phase. Azoreductase produced intracellularly had the highest specific activity of $0.334 \mathrm{U} / \mathrm{mg}$ compared to the culture supernatant (extracellular), resting cell and cell debris with low enzyme activity of $0.034 \mathrm{U} / \mathrm{mg}, 0.010 \mathrm{U} / \mathrm{mg}$ and $0.200 \mathrm{U} / \mathrm{mg}$ respectively. The optimum assay conditions for the maximum azoreductase activity were at $37^{\circ} \mathrm{C}, \mathrm{pH} 7, \mathrm{RB} 5$ dye concentration of $100 \mathrm{mg} / \mathrm{L}$ and $\mathrm{NADH}$ concentration of $0.2 \mathrm{mM}$ by using phosphate buffer as a medium for the enzyme reaction. Alternatively, the azoreductase assay was also carried out using ionic liquid, [emim] $\left[\mathrm{EtSO}_{4}\right]$ that may function to enhance the activity and stability of azoreductase. Results using phosphate buffer ( $\mathrm{pH}$ 7) showed higher enzyme activity twice that of the ionic liquid besides enhancing the stability of enzyme. Under the optimum assay conditions up to $93 \%$ of decolourisation was achieved after $8 \mathrm{~h}$ of incubation. In addition, growth of bacteria was also concurrently observed during the
\end{abstract} decolourisation of RB5.

Keywords: Azoreductase; brevibacillus panacihumi ZBI; reactive Black 5; decolourisation; azoreductase assay

\begin{abstract}
Abstrak
Enzim azoreduktase sering dikaitkan dengan proses penyahwarnaan pewarna azo melalui pembelahan ikatan azo. Brevibacillus panacihumi ZBI, bakteria yang belum pernah dilaporkan sebelum ini berfungsi untuk mendegradasi pewarna azo telah digunakan bagi tujuan penyahwarnaan Reactive Black 5 (RB5). Aktiviti enzim azoreduktase yang paling tinggi dihasilkan pada penghujung fasa log. Enzim azoreduktase yang telah dihasilkan secara intrasel mempunyai aktiviti enzim spesifik yang paling tinggi iaitu 0.334 $\mathrm{U} / \mathrm{mg}$ berbanding dengan kultur supernatan (ekstrasel), sel tidak aktif dan serpihan sel yang mempunyai aktiviti enzim yang rendah iaitu $0.034 \mathrm{U} / \mathrm{mg}, 0.010 \mathrm{U} / \mathrm{mg}$ dan $0.200 \mathrm{U} / \mathrm{mg}$ masing-masing. Keadaan asai yang optimum bagi menghasilkan aktiviti enzim azoreduktase yang maksimum adalah pada $37^{\circ} \mathrm{C}, \mathrm{pH}$, pewarna azo RB5 $100 \mathrm{mg} / \mathrm{L}$ dan kepekatan NADH,0.2 mM dengan menggunakan penimbal fosfat sebagai medium untuk tindak balas enzim. Sebagai cara alternatif, asai azoreduktase telah dijalankan dengan menggunakan cecair ion [emim] $\left[\mathrm{EtSO}_{4}\right]$ yang berfungsi untuk meningkatkan aktiviti dan kestabilan enzim azoreduktase. Keputusan menggunakan penimbal fosfat, $\mathrm{pH} 7$ telah menunjukkan aktiviti enzim dua kali ganda lebih tinggi daripada cecair ion disamping meningkatkan kestabilan enzim azorduktase. Pada keadaan asai optimum, sehingga $93 \%$ penyahwarnaan telah berlaku selepas jam kelapan inkubasi. Di samping itu, pertumbuhan bakteria berlaku serentak semasa penyahwarnaan RB5.
\end{abstract}

Kata kunci: Azoreduktase; brevibacillus panacihumi ZBI; Reactive Black 5; penyahwarnaan; asai azoreduktase

(C) 2012 Penerbit UTM Press. All rights reserved.

\subsection{INTRODUCTION}

Water pollution has become a major concern to the society since the past few decades. Approximately 280,000 tonnes of dyes has been discarded to the environment annually [1]. Azo dye is being widely used as the colouring agent in textile industries because of its lower production cost and has more variations in colour compared to natural dyes. A major environmental concern in the release of coloured effluents is the high content of dye chemicals 
and their breakdown products may even be more toxic and/or mutagenic to aquatic life [2].

At present, the removal of colour from dye-containing water and wastewater, especially that of textile wastewaters, is a difficult task; there is no economical treatment that can effectively treat dyes. Most of them use chemical treatment which adds more pollutant such as generation of toxic sludge which requires special handling procedures prior to disposal as scheduled wastes.

A good alternative treatment method for dye-containing wastewater is to bioaugment effective azo dye-degrading microorganisms capable of decolourising and degrading azo dyes. Besides reducing the amount of toxic compounds [3] in the wastewater, it is environmentally friendly and cost-effective.

In this study, Brevibacillus panacihumi ZBI which was previously isolated by our researcher was used to decolourise and degrade azo reactive dye, Reactive Black 5 using the combination of anaerobic-aerobic treatment.

\subsection{RESEARCH SIGNIFICANCE}

Azoreductases are generally responsible for reducing the azo double bond in azo dyes structures. They undergo enzymatic biotransformation to produce colourless aromatic amines which are more toxic than the parent compound. In this study, for the first time azoreductase produced by Brevibacillus panacihumi $\mathrm{ZBI}$ is reported to decolourise reactive azo dye, Reactive Black 5, which is recalcitrant towards microbial degradation. Therefore, it is important to study the characteristics of azoreductase-mediated degradation since azoreductases isolated from different microorganisms are known to have broad specificities in their enzymatic reactions [9]. This finding may further contribute to highly adaptable bacteria with good potential application for treatment of azo-containing wastewater. Hence it is of great interest to investigate factors affecting its enzyme activities such as $\mathrm{pH}$, temperature, substrate concentration, NADH concentration during decolourising of Reactive Black 5. In addition, ionic liquid which may influence activity and stability of enzyme was also studied to determine if it can be used as an alternative solvent for the enzyme reaction.

\subsection{BIOLOGICAL TREATMENT OF TEXTILE WASTE WATER}

Azo dyes have been extensively used in the textile industries as colouring agents. A major problem associated with the use of this type of dye is that it is recalcitrant towards microbial degradation. An effective biological treatment of azo dyes will include enzymatic decolourisation and subsequent degradation of decolourised compounds for safer discharge of the effluent. Azoreductase enzyme that are produced during the decolourisation, catalyzes the reductive cleavage of azo bond resulting in the colour removal of azo dyes and occurs preferentially under anaerobic or facultative condition. Aromatic amines that are produced however, are more toxic to human and aquatic life than the parent compound. Hence for complete degradation or mineralization of azo dyes, a combination of the anaerobic process is necessary for the decolourisation of azo dyes into colourless aromatic amines and aerobic process to further oxidize aromatic amines into less toxic and readily degradable compounds [4].

Azoreductase enzymes have been isolated from various types of microorganisms. These enzymes are of broad specificities and can either be tolerant or sensitive to oxygen. Their activities may be flavin-dependent or may not require flavin [5]; studies on specific characteristic of azoreductases were reported in microorganisms such as Enterobacter agglomerans [6], Staphylococcus aureus [7] and Micrococcus strain [8]. Several species of mammalian intestinal bacteria had also been reported to have azoreductase activities. Some examples of these bacteria include Shigella [5], Escherichia coli [9], Enterococcus faecalis and Staphylococcus aureus [7]. Nevertheless, studies of azo dyedegrading fungi have also been established in several reports that include Trametes versicolor, Phanerochaete chrysosporium and Phlebia tremellosa [10]. Another example of fungi was Issatchenkia occidentalis which was used for decolourisation of methyl orange and orange II [11].

In previous studies, anaerobic systems are mainly used since most of the azo dyes used in textile industries are resistant towards microbial degradation under aerobic conditions [13]. However, few studies have been reported to involve aerobic conditions to degrade azo dyes $[6,8,11]$. Most of the successful decolourisation of textile wastewater use the combination of anaerobic and aerobic treatment $[7,11,14,15,16,17]$ process.

\subsection{IONIC LIQUID}

Ionic liquids are low melting $\left(<100^{\circ} \mathrm{C}\right)$ salts and a new class of solvents that have been widely used for enzymatic catalysis [19]. They are present as nonvolatile, negligible vapor pressure, nonflammable and highly stable solvents. These organic solvents are of high potential use in substituting conventional organic solvents in catalytic and synthetic reactions [20]. Ionic liquids are of a great interest among researchers because of their properties that are capable of improving the activity, stability, substrate solubility, yield and selectivity of enzyme as compared to the conventional organic solvents.

1- ethyl-3- methylimidazolium ethylsulfate [emim] [ $\left.\mathrm{EtSO}_{4}\right]$ has been used throughout this study because it is one of the most promising ionic liquid used to enhance the performance enzyme in terms of its activity [21]. This ionic liquid has been proven to increase the activity of glucose oxidase and laccase enzyme [21, 22]. The effect of ionic liquid on enzyme performance is largely influenced by the enzyme structure, the substrate and the water molecules associated with the enzyme [23]. Ionic liquids offer several advantages for the application in numerous synthetic processes and this work has been extensively described by Noritomi and co-workers. These advantages include the solubility of non-polar reactants and product improvements such as thermostability of enzymes, the enhanced stereoselectivity and favorable thermodynamic equilibria [24].

\subsection{METHODOLOGY}

In this research, Brevibacillus panacihumi ZBI was obtained from Microbial Collection of Makmal Penyelidikan 2 (MP2), Faculty of Biosciences and Bioengineering, UTM.

\subsection{Growth of Brevibacillus panacihumi}

The single colony of Brevibacillus panacihumi ZBI from the stock culture was transferred into $50 \mathrm{~mL}$ of nutrient broth and grown under aerobic conditions at $37{ }^{\circ} \mathrm{C}$ for $24 \mathrm{~h}$. The culture medium contained $10 \mathrm{~mL}$ of inoculums $(\mathrm{v} / \mathrm{v}), 39.2 \mathrm{~mL}$ of Reactive Black $5100 \mathrm{mg} / \mathrm{L}, 0.6 \mathrm{~mL}$ yeast extract $1.2 \%(\mathrm{v} / \mathrm{v})$ and $0.2 \mathrm{~mL}$ glucose $0.4 \%(\mathrm{v} / \mathrm{v})$. This medium was incubated at $37^{\circ} \mathrm{C}$ under anaerobic condition until decolourisation was observed after which the culture medium was incubated under aerobic condition in the shaking incubator at $37^{\circ} \mathrm{C}, 150 \mathrm{rpm}$. Growth was 
indirectly measured from the absorbance of cell suspension using a spectrophotometer at $600 \mathrm{~nm}$. The decolourisation of Reactive Black 5 was determined using American Dye Manufacturing Institute (ADMI) method and measured at $597 \mathrm{~nm}$ using $\mathrm{HACH}$ spectrophotometer.

\subsection{Azoreductase Assay}

Azoreductase assay was carried out according to the modification of method described by Moutaouakkil et al. (2003) [6]. The amount of Reactive Black 5 decolourised was determined using a standard curve of the absorbance $\left(\mathrm{A}_{597}\right)$ versus Reactive Black 5 concentrations. One Unit (U) of azoreductase activity was defined as $1 \mu \mathrm{mol}$ of Reactive Black 5 decolourised per minute. Protein concentration of azoreductase was determined using Lowry method [25] and Bovine Serum Albumin (BSA) as the standard protein.

\subsection{Determination of Azoreductase Localisation}

To determine azoreductase localisation, the experiment was carried out according to the modified of method described by Moutaouakkil et al. (2003) [6]. The absorbance was measured at $597 \mathrm{~nm}$.

5.4 Effect of PH, Temperature, Substrate Concentration, NADH Concentration and Ionic Liquid Concentration on Activity and Stability of Azoreduactase

To determine the effect of $\mathrm{pH}$ on the activity of the enzyme, three different buffer systems were used for $\mathrm{pH}$ ranging from 3.0-9.0; the buffer systems were acetate buffer ( $\mathrm{pH} 3-5)$, phosphate buffer ( $\mathrm{pH}$ 6-8) and Tris- $\mathrm{HCl}(\mathrm{pH} 9)$. To determine the optimum temperature, the incubation temperature was varied in the range of $25{ }^{\circ} \mathrm{C}$ to $70{ }^{\circ} \mathrm{C}$. The azoreductase activity was also determined at substrate concentration ranging from $50 \mathrm{mg} / \mathrm{L}$ to $150 \mathrm{mg} / \mathrm{L}$. In addition, the effect of NADH concentration on the enzyme activity was also determined. To investigate if ionic liquid can improve the enzyme activity and stability, 1-ethyl-3-dimethyl imidazolium ethylsulfate $[\mathrm{emim}]\left[\mathrm{EtSO}_{4}\right]$ was used instead of the phosphate buffer. The stability of azoreductase was investigated using the same method as above with an extended reaction time of 1 hour.

\section{ם6.0 RESULTS AND DISCUSSIONS}

Enzyme-mediated decolourisation is is an efficient method in dye containing effluent and currently is of great interest in the biological treatment of textile wastewater. From previous studies, crude and purified azoreductases were able to decolourise different textile dyes such as Reactive Violet 5 [26], Reactive Black 5 [16], Methyl Red [6] and Acid Orange 7 [27], to mention a few. The rate of decolourisation for each type of azo dye is expected to vary within minutes to hours depending on the type of azo bonds and the structural complexity of the azo dyes. Hence the presence of a bacterial azoreductase to decolourise Reactive Black 5 makes Brevibacillus panacihumi ZBI important for textile wastewater treatment. Figure 4.1 below shows the decolourisation of Reactive Black 5 under facultative anaerobic condition and subsequent aerobic process. The combined condition allowed the decolourisation process to occur during which growth was also observed as displayed by a typical growth profile of Brevibacillus panacihumi ZBI during 48 hours of incubation. It is interesting to note that exponential growth was observed during facultative anaerobic condition in contrast to what has been reported in many studies whereby the most active growth phase occurred during the aerobic condition. This may imply complete breakdown or mineralisation process of RB5 may involve azoreductase and oxido-reductases of Brevibacillus panacihumi ZBI that are induced under the facultative anaerobic condition.

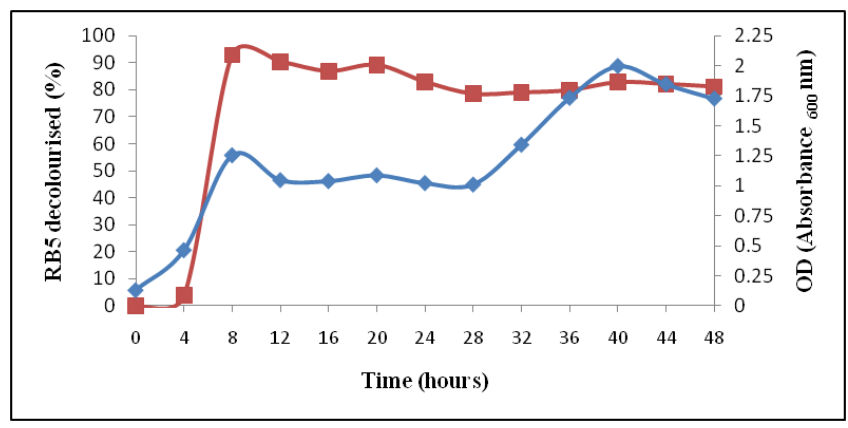

Figure 4.1 Decolourisation of Reactive Black 5 by Brevibacillus panacihumi ZBI under sequential anaerobic-aerobic system. $($ = percentage of dye decolourised; = optical density as indirect measurement of bacterial growth)

As shown in Figure 4.1, the maximum percentage of dye decolourised was up to $93 \%$ for Reactive Black 5 after 8 hour of incubation which corresponded to the end of exponential growth phase. Significant increase in biomass in this phase may subsequently influence the decolourisation during anaerobic condition. In previous studies however, the decolourisation of azo dyes by Enterobacter sp. EC3 took about 60 to 108 hours to achieve between $78.4 \%$ to $92.6 \%$ of decolourisation [28]. Comparatively, Brevibacillus panacihumi ZBI showed higher decolourisation of Reactive Black 5 dye within a shorter period of time. Since the bacterium was able to grow during the facultative anaerobic condition and reached its maximum growth under aerobic condition, it may be concluded that Brevibacillus panacihumi $\mathrm{ZBI}$ is a facultative anaerobic bacterium with the ability to grow in the presence of oxygen as well as limited amount of oxygen. Results from this study showed that decolourisation of Reactive Black 5 was preferred under anaerobic condition since decolourisation of azo dyes in the presence of oxygen might be inhibited due to the competition between oxygen and azo bonds to be reduced by electron from electron carriers such as NADH.

The localisation of azoreductase was studied in four types of cell fraction which were culture supernatant (CS), cell free extract (CFE), resting cell (RC) and cell debris (CD). These four fractions were tested for enzyme activity using azoreductase assay. The enzyme activity for each fraction was significantly lower than the fraction of cell free extract. The cell free extract showed the highest specific activity compared to the other fractions which the enzyme activity was $0.334 \mathrm{U} / \mathrm{mg}$. The culture supernatant which represented the extracellular fraction had significantly lower enzyme activity of $0.034 \mathrm{U} / \mathrm{mg}$. Hence, the localisation of azoreductase was probably the bacterial cytoplasm. This suggested that the bacterial membranes could act as efficient barriers for the uptake of sulfonated azo dyes. Several similar findings have been reported on azoreductase that are produced intracellularly by bacterial species such as Bacillus sp. Strain SF, Lactobacillus casei TISTR 1500 and Bacillus sp. B29 [16, 30, 31].

For the optimization of the azoreductase assay, a typical bellshaped profile was obtained for $\mathrm{pH}$ optimisation as shown in Figure 4.4. The highest enzyme activity, $0.332 \mathrm{U} / \mathrm{mL}$ was found to be at $\mathrm{pH}$ 7. This finding was similar to the studies reported by 
Moutaouakkil et al. (2003) and Maier et al. (2004) [6, 16]. The decolourisation of textile wastewater usually occurred at neutral $\mathrm{pH}$ or slightly alkaline $\mathrm{pH}$. The extreme $\mathrm{pH}$ exhibited a decrease in enzyme activity due to protein denaturation at high $\mathrm{pH}$ and protein inactivation at low $\mathrm{pH}$. This is caused by the changes of the enzyme structure especially at the active site [30]. This enzyme was found to be most stable at $\mathrm{pH} 7$ with the activity of $0.301 \mathrm{U} / \mathrm{mL}$. Furthermore, the azoreductase activity was slightly higher at the alkaline $\mathrm{pH}$. Hence, this enzyme can be categorised into alkaline-tolerant enzyme. Maier et al. (2004) has reported that an alkali-thermostable azoreductase was successfully isolated from Bacillus sp. Strain SF which has significantly similar $\mathrm{pH}$ stability with azoreductase produced from Brevibacillus panacihumi ZBI [16]. The stability of enzyme decreased drastically with the change of $\pm 1 \mathrm{pH}$ unit. This may be due to the loss of cell viability that is caused by the conformational changes in the protein structure.

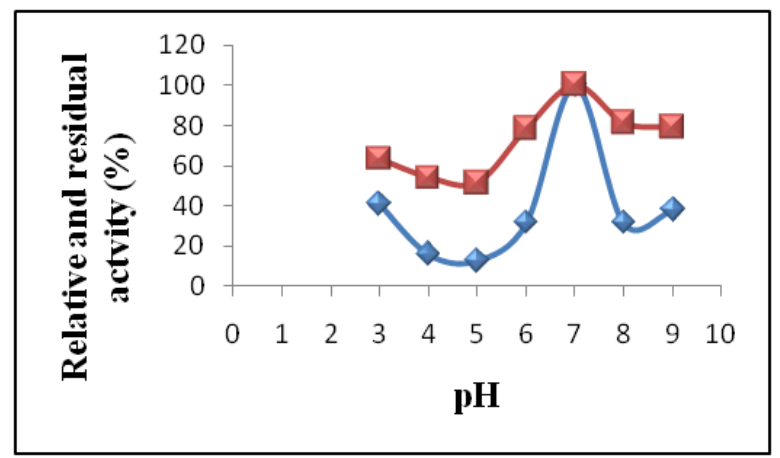

Figure 4.4 The effect of $\mathrm{pH}$ on azoreductase activity and stability

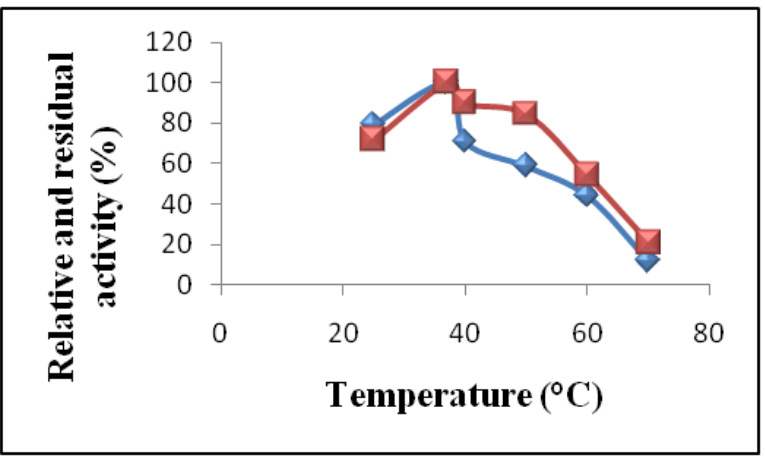

Figure 4.5 The effect of temperature on azoreductase activity and stability

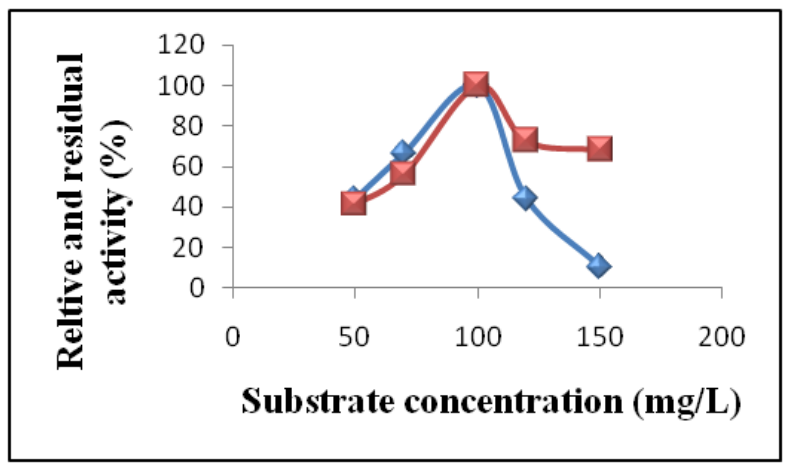

Figure 4.6 The effect of substrate concentration on azoreductase activity and stability

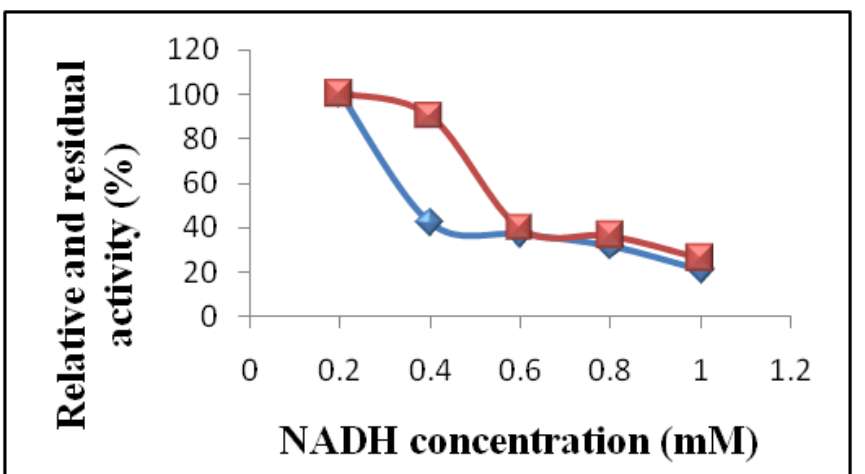

Figure 4.7 The effect of NADH concentration on azoreductase activity and stability

relative activity $(\%) ; \diamond=$ azoreductase activity residual activity $(\%) ; n=$ azoreductase stability

Figure 4.5 shows the optimum temperature for azoreductase assay was $37^{\circ} \mathrm{C}$. The acclimatisation of this bacterial growth in a specific medium culture has likely influenced its optimum activity during azoreductase assay. Decolourisation of Reactive Black 5 and azoreductase activity was significantly reduced at $40^{\circ} \mathrm{C}$ and above. This result might be due to the loss of cell viability and deactivation of the enzyme that is responsible for catalysing the reductive cleavage of azo dye at high temperature [32]. In addition, elevated temperatures could denature the enzyme. Hence, the enzyme active site would be disrupted causing the active site to undergo conformational changes. As shown in Figure 4.5, the azoreductase extracted from B.panacihumi ZBI was most stable at $37{ }^{\circ} \mathrm{C}$ with the azoreductase activity of 0.312 $\mathrm{U} / \mathrm{mL}$. The azoreductase was slightly stable at the temperature of $40{ }^{\circ} \mathrm{C}$ and $50{ }^{\circ} \mathrm{C}$. Moutaouakkil et al. (2003), reported that the stability of azoreductase from Enterobacter agglomerans was influenced by the thermal inactivation above $40{ }^{\circ} \mathrm{C}$ and further increase in temperature to $60{ }^{\circ} \mathrm{C}$ reduced the enzyme stability drastically [6]. This may also resulted in the total loss of enzyme activity.

Enzymatic assay was also performed by varying concentration of RB5. The optimum substrate concentration was found to be $100 \mathrm{mg} / \mathrm{L}$ with enzyme activity of $0.309 \mathrm{U} / \mathrm{mL}$ (Figure 4.6). At lower concentration of the RB5 (below 100 $\mathrm{mg} / \mathrm{L}$ ), increase in concentration showed proportional increase in enzyme activity. However, increase in dye concentration above $100 \mathrm{mg} / \mathrm{L}$ caused a drastic reduction of the enzyme activity. Higher concentrations of azo dyes may exert its toxic effects, affecting viability and subsequent decolourisation abilities [33]. Another plausible explanation is the saturation of enzyme binding sites. Similarly, the stability of azoreductase showed optimum azoreductase activity of $0.303 \mathrm{U} / \mathrm{mL}$ at substrate concentration of $100 \mathrm{mg} / \mathrm{L}$

Figure 4.7 shows the effect of NADH concentrations on azoreductase activity. NADH is an important redox mediator that supply electrons to reduce the azo bonds [16]. The maximum enzyme activity was found to be $0.319 \mathrm{U} / \mathrm{mL}$ using $0.2 \mathrm{mM}$ $\mathrm{NADH}$. Further increase in NADH concentration significantly reduced the enzyme activity. This might be due to the excess consumption of $\mathrm{NADH}$ in oxidative phosphorylation pathway (during the aerobic process) that affects the decolourisation of 
azo bonds [30, 32]. The azoreductase was found to be most stable at $0.2 \mathrm{mM}$ and slightly less stable at $0.4 \mathrm{mM}$. The stability of this enzyme was significantly decreased with further increase of NADH concentration above $0.4 \mathrm{mM}$. This observation is in contrast to the previous observations which reported that azoreductase activity has a linear dependence with NADH concentration up to $1.5 \mathrm{mM}$ and further increase of concentration did not increase the reaction velocity [16].

As an alternative medium for the enzymatic reaction, ionic liquid was used instead of phosphate buffer. This solvent has become a great interest amongst researchers due to its high thermal stability, low volatilities and low flammability [33]. In this study, the ionic liquid used was 1-ethyl-3-dimethyl imidazolium ethyl sulfate $[\mathrm{emim}]\left[\mathrm{EtSO}_{4}\right]$. The presence of this non-aqueous solvent is required to increase the solubility of the reaction mixtures for azoreductase assay. The maximum activity of azoreductase was found to be at $70 \%$ concentration of [emim] $\left[\mathrm{EtSO}_{4}\right]$ which shows the activity of $0.116 \mathrm{U} / \mathrm{mL}$. According to Yang et al. (2008), the enzyme activity was altered by the repelling effect of the ionic liquid on the dynamics and conformation of the enzyme [34].

Based on the results shown in Figure 4.8, the activity of enzyme tested using ionic liquid was significantly lower than that of the phosphate buffer. It should be noted that most of the previous studies reported on the use of ionic liquid in the enzymatic studies of cellulose, protease and amylase. According to Tavares et al. (2008), high concentration of ionic liquid caused a decrease in enzyme activity besides causing the enzyme to precipitate out of solution [22]. Similar results of enzyme precipitation in ionic liquid were also observed with $[\mathrm{emim}]\left[\mathrm{EtSO}_{4}\right]$ at higher concentration $(75 \%(\mathrm{v} / \mathrm{v})$ and above). The azoreductase was found to be most stable at $30 \%$ of ionic liquid concentration with the azoreductase activity of 0.157 $\mathrm{U} / \mathrm{mL}$. The lower concentration of ionic liquid shows slightly higher enzyme stability compared to the higher concentration of ionic liquid. This may be due to the delayed reaction between azoreductase and a lower concentration of $[\mathrm{emim}]\left[\mathrm{EtSO}_{4}\right]$. The reaction mixture becomes more saturated and azoreductase loses its activity because of excess ionic liquid.

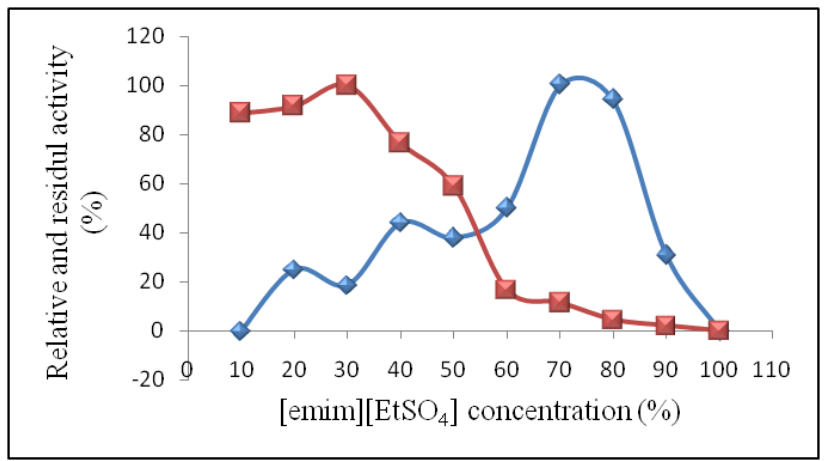

Figure 4.8 The effect of Ionic liquids concentration on azoreductase activity and stability $(\diamond=$ activity; $\square=$ stability)

The enzyme activity decreased drastically after further increase in $[\mathrm{emim}]\left[\mathrm{EtSO}_{4}\right]$ concentration above $30 \%$. It was assumed that the high concentration of $[\mathrm{emim}]\left[\mathrm{EtSO}_{4}\right]$ led to the total loss of enzyme activity. Duplissa et al. (2010) suggested that enzyme could maintain its activity a higher concentration of ionic liquid, if it is diluted with phosphate buffer instead of water [35]. The combination of water structuring and direct interactions between the ions and the protein could help to stabilise the enzyme structure. In addition, the enzyme activity was significantly decreased at high ionic liquid content because of the mass-transport limitation.

As a conclusion, the optimum assay conditions for the maximum azoreductase activity were found to be at $37^{\circ} \mathrm{C}, \mathrm{pH} 7$, RB5 dye concentration of $100 \mathrm{mg} / \mathrm{L}$ and $\mathrm{NADH}$ concentration of $0.2 \mathrm{mM}$. Phosphate buffer was used to stabilise and minimise the changes in the reaction mixture of azoreductase assay. Results showed that ionic liquid $[\mathrm{emim}]\left[\mathrm{EtSO}_{4}\right]$ cannot be used to enhance azoreductase activity. Further studies using other ionic liquid can be carried out to fully explore the potential of these organic solvents to enhance enzyme activity and stability. Decolourisation of Reactive Black 5 was successfully achieved up to $93 \%$ under the optimized assay condition after $8 \mathrm{~h}$ hours of incubation.

\section{Acknowledgement}

This research is funded under Fundamental Research Grant Scheme (4F018). The third author, H.H. Bay would like to thank Universiti Teknologi Malaysia and Ministry of Higher Education (MOHE) for ZAMALAH scholarship while the fourt author, C.K. Lim would like to extend his gratitude to Ministry of Science, Technology and Innovative (MOSTI) for awarding him NSF scholarship.

\section{References}

[1] Jin, X. C., Liu, G. Q., Xu, Z. H., and Tao, W. Y. 2007. Decolourization of a Dye Industry Effluent by Aspergillus fumigates XC6. Applied Microbiology and Biotechnology. 74: 239-243.

[2] Jadhav, J. P., Kalyani, D. C., Telke, A. A., Phugare, S. S., and Govindwar, S. P. 2010. Evaluation of the Efficacy of a Bacterial Consortium for the Removal of Colour, Reduction of Heavy Metals and Toxicity from Textile Dye Effluent. Bioresources Technology. 101: 165173.

[3] Forgacs, E., Cserhati, T., and Oros, G. 2004. Removal of Synthetic Dyes from Wastewaters. A Review. Environmental International. 30: 953971.

[4] Dafale, N., Wate, S., Meshram, S., and Neti, R. N. 2010. Bioremediation of Wastewater Containing Azo Dyes Through Sequential AnaerobicAerobic Bioreactor System and Its Biodiversity. Environmental Reviews. 18: $21-36$.

[5] Ghosh, D. K., Mandal, A., and Chaudhuri, J. 1992. Purification and Partial Characterization of Two Azoreductases from Shigella Dysenteriae Type1, FEMS Microbiology Letters. 77: 229-233.

[6] Moutaouakkil, A., Zeroual, Y., Dzayri, F. Z., Talbi, M., Lee, K., and Blaghen, M. 2003. Purification and Partial Characterization of Azoreductase From Enterobacter agglomerans. Archieves of Biochemistry and Biophysics. 413: 139-146.

[7] Chen, H., Hopper, S. L., and Cerniglia, C. E. 2005. Biochemical And Molecular Characterization of an Azoreductase From Staphylococcus aureus, a tetrameric NADPH-Dependent Flavoprotein. Microbiology. 151: 1433-1441.

[8] Olukanni, O. D., Osuntoki, A. A., and Gbenle, G. O. 2009. Decolourization of Azo Dye by a Strain of Micrococcus Isolated from a Refuse Dump Soil. Biotechnology. 8: 442-448.

[9] Nakanishi, M., Yatome, C., Ishida, N., and Kitade, Y. 2001. Putative ACP Phosphodiesterase Gene (acpD) Encodes an Azoreductase. Journal of Biological Chemistry. 276: 46394-46399.

[10] Kirby, N., Marchant, R. and McMullan, G. 2000. Decolourization of Synthetic Textile Dyes by Phlebia tremellosa. FEMS Microbiology Letters. 188: 93-96.

[11] Ramalho, P. A., Cardoso, M. H., Paulo, A. C., and Ramalho, M. T. 2004. Characterization of Azo Reduction Activity in a Novel Ascomycetes Yeast Strain. Applied and Environmental Microbiology. 70: 2279-288.

[12] McMullan, G., Meehan, C., Conneely, A., Kirby, N., Robinson, T. Nigam, P., Banat, I. M., Marchant, R. and Smyth, W. F. 2001. Microbial Decolourisation and Degradation of Textile Dyes. Applied Microbiology and Biotechnology. 56: 81-87.

[13] Van Der Zee. 2002. Anaerobic Azo Dye Reduction. Doctorial Thesis, Wageningen University. 
[14] Puvaneswari, N., Muthukrishnan, J., and Gunasekaran, P. 2006. Toxicity Assessment and Microbial Degradation of Azo Dyes. Indian Journal of Experimental Biology. 44: 618-626.

[15] Supaka, N., Juntongjin, K., Damronglerd, S., Delia, M. L., and Strehaiano, P. 2004. Microbial Decolourisation of Reactive Azo Dyes in a Sequential Anaerobic-Aerobic System. Chemical Engineering Journal. 99: 169-176.

[16] Maier, J., Kandelbauer, A., Erlacher, A., Cavaco-Paulo, A., and Gubitz, G. M. 2004. A New Alkali-Thermostable Azoreductase from Bacillus sp. Strain SF. Applied and Environmental Microbiology. 70: 837-844.

[17] Chong, C. S., Ibrahim, Z., Md Salleh, M., Abdul Rashid, N. A., Yahya A., and Wong, W. J. 2006. Decolourization of Azo Dye Direct Blue 15 Using Batch Culture of Klebsiella sp. Petroleum and Natural Resources Process. Regional Conference of Post-graduate for Engineering and Science, School of Post-graduate Studies, Universiti Teknologi Malaysia, 26 -27 July.

[18] Russ, R., Rau, J., and Stolz, A. 2000. The Function of Cytoplasmic Flavin Reductases In The Reduction of Azo Dyes By Bacteria. Applied and Environmental Microbiology. 66: 1429-1434.

[19] Cull, S. G., Holbrey, J. D., Vargas-Mora, V., Seddon, K. R., and Lye, G. J. 2000. Room-temperature Ionic Liquids as Replacements For Organic Solvents in Multiphase Bioprocess Operations. Biotechnology and Bioengineering. 69: 227-233.

[20] Wasserscheid, P. and Welton, T. 2002. Ionic Liquids in Synthesis. Berlin Wiley-VCH

[21] Santafé, A. A., Doumèche, B., Blum, L. J., Girard-Egrot, A. P., Marquette, C. A. 2010. 1-Ethyl-3-methylimidazolium ethylsulfate/copper Catalyst for the Enhancement of Glucose Chemiluminescent Detection: Effects on Light Emission and Enzyme Activity. Analytical Chemistry. 82: $2401-4$

[22] Tavares, A. P. M., Rodriguez, O., and Macedo, E. A. 2008. Ionic Liquids as Alternative Co-solvents for Laccase: Study of Enzyme Activity and Stability. Biotechnology and Bioengineering. 101: 201-207

[23] Yang, Z., Yue, Y. J., Huang, W. C., Zhuang, Z. M., Chen, Z. T., and Xing, M. 2009. Importance of the Ionic Nature of Ionic Liquids in Affecting Enzyme Performance. Journal of Biochemistry. 145: 355-364.

[24] Noritomi, H. 2011. Protease-Catalyzed Synthetic Reactions in Ionic Liquids, Ionic Liquids: Applications and Perspectives, Alexander Kokorin (Ed.), ISBN: 978-953-307-248-7, InTech, Available from: http://www.intechopen.com /articles/show/title/protease-catalyzedsynthetic-reactions-in-ionic-liquids.

[25] Lowry, O. H., Rosenbrough, N. J., Farr, A. I., and Randall, R. J. 1951 Protein Measurement with the Folin Phenol Reagent. Journal of Biology and Chemistry. 193: 265-275.

[26] Moosvi, S., Keharia, H., and Madamwar, D. 2005. Decolourization of Textile Dye Reactive Violet 5 by a Newly Isolated Bacterial Consortium RVM 11.1. World Journal of Microbiology and Biotechnology. 21: 667672 .

[27] Gottlieb, A., Shaw, C., Smith, A., Wheatley, A., and Forsythe, S. 2001. The Toxicity of Textile Reactive Azo Dyes after Hydrolysis and Decolourisation. Journal of Biotechnology. 101: 49-56.

[28] Wang, H., Zheng, X. W., Su, J. Q., Tian, Y., Xiong, X. J., and Zheng, T. L. 2009. Biological Decolourisation of The Reactive Dyes Reactive Black 5 by A Novel Isolated Bacterial Strain Enterobacter sp. EC3. Journal of Hazardous Materials. 171: 654-659.

[29] Seesuriyachan, P., Shinji, T., Ampin, K., Srikarnjana, K., Shuichiro, M., and Kenji, A. 2007. Metabolism of Azo Dyes By Lactobacillus Casei TISTR 1500 and Effects of Various Factors on Decolourisation. Water Research. 41: 985-992.

[30] Choong, L. Y. 2004. Enzymatic Studies on Azoreductase from Enterococcus Strain C1 that Decolourizes Azo Dyes. B. Sc. Thesis, Universiti Teknologi Malaysia, Johor Bahru

[31] Ooi, T., Shibata, T., Sato, R., Ohno, H., Kinoshita, S., and Thuoc, T.L. et al. 2007. An Azoreductase, Aerobic NADH-Dependent Flavoprotein Discovered From Bacillus sp. Functional Expression and Enzymatic Characterization. Applied Microbiology and Biotechnology. 75: 377-386.

[32] Panswad, T., and Luangdilok, W. 2000. Decolourisation of Reactive Dyes with Different Molecular Structures Under Different Environmental Conditions. Water Research. 34: 4177-4184.

[33] Basso, A., Cantone, S., Linda, P., and Ebert, C. 2005. Stability and Activity of Immobilsed Penicilin G Amidase In Ionic Liquids At Controlled $\mathrm{a}_{\mathrm{w}}$. Green Chemistry. 7: 671-676.

[34] Yang, Z., Yue, Y., and Xing, M. 2008. Tyrosinase Activity in Ionic Liquids. Biotechnology Letters. 30: 153-158.

[35] Duplissa, L., Andreescu, S., Baltus, R., and Njagi, J. 2010. Interactions of Room Temperature Ionic Liquids with Enzymes: Characterization and Activity Studies. Chemical Engineering REU. 53: 432-436. 